\title{
Informal and formal mechanisms of coordination in hybrid food value chains
}

\author{
J. Dara Bloom ${ }^{a}{ }^{*}$ and C. Clare Hinrichs ${ }^{\mathrm{b}}$
}

Submitted 22 February 2011 / Accepted 3 May 2011 / Published online 17 August 2011

Citation: Bloom, J. D., \& Hinrichs, C. C. (2011). Informal and formal mechanisms of coordination in hybrid food value chains. Journal of Agriculture, Food Systems, and Community Development, 1(4), 143-156. http://dx.doi.org/10.5304/jafscd.2011.014.016

Copyright (C 2011 by New Leaf Associates, Inc.

\begin{abstract}
The challenges of meeting growing consumer demand for local food, especially from larger, institutional buyers, has sparked many to look beyond direct marketing to alternative models of produce aggregation and distribution. Value chains that incorporate conventional food system infrastructure are one such model for local food system development, but little research has studied their functioning and outcomes. Arrangements where conventional produce distributors handle local food can be viewed as "hybrid" food value chains, since they include both local and global resources, and combine conventional food system infrastructure with the more alternative goal of building local food systems. This qualitative study examines three hybrid food value chains that revolve around con-

\footnotetext{
${ }^{a}$ Department of Agricultural Economics and Rural Sociology, Armsby Building, Pennsylvania State University, University Park, PA 16801 USA

b Department of Agricultural Economics and Rural Sociology, Armsby Building, Pennsylvania State University, University Park, PA 16801 USA; chinrichs@psu.edu

* Corresponding author: J. Dara Bloom; +1-814 865 5461; jdb439@psu.edu
}

ventional, wholesale produce distributors located in rural, urban, and exurban regions of Pennsylvania. Theories of local and social embeddedness inform the analysis of how participants negotiate and coordinate their interactions through informal mechanisms, such as their social relationships, and formal mechanisms, such as contracts and labels. Case study findings reveal distinctions between the rural and exurban cases on the one hand, where participants combined both personal and market-based mechanisms to coordinate their relationships, and the urban case, where the sale of specialty products to a niche market both fostered and inhibited the use of more formal mechanisms of coordination. In all cases, commercial conventions tended to take precedence over social relationships, despite the role that personal trust may have played. These findings suggest that when value chains incorporate conventionally oriented businesses, they would benefit from more deliberate commitment to noneconomic goals in order to establish successful mechanisms of interorganizational coordination.

\section{Keywords}

case study, embeddedness, food distributor, food value chain, local food, Pennsylvania 


\section{Introduction}

Many efforts to change the food system now sound the mantra of "cutting out the middleman." Direct marketing relationships between producers and consumers are said to counter the faceless anonymity of conventional marketplaces and allow producers to retain higher profits (Hinrichs, 2000; Kirwan, 2006). However, direct marketing approaches may not have the capacity, both in terms of the volume of available produce in a given area, as well as the needed infrastructure, to meet the growing demand for local, sustainable food (Friedmann, 2007). This is especially true in the case of schools and other institutions, which struggle with the additional burdens of constrained budgets and finding consistent volume, supply, and quality, as well as coordinating pick-up, delivery, and processing of fresh produce (Hinrichs \& Schafft, 2008).

In cases where direct marketing relationships are challenged by these constraints, local food system development may benefit from short food supply chains that utilize local, but conventional food system infrastructure. However, when the marketing of local produce extends beyond direct relationships, challenges can arise from the need to coordinate production and demand, as well as to regulate quality (Barham, 2002; Wolf, Hueth, \& Ligon, 2001). The way that supply chains are coordinated and regulated has implications for the balance of power between producers and marketing intermediaries. In the conventional food system, producers tend to be at a disadvantage in marketing relationships, where they effectively lose ownership over the products they raise and the prices they receive (Hendrickson \& Heffernan, 2002; Hinrichs \& Welsh, 2003; Stevenson \& Pirog, 2008). In contrast, local and alternative food system supporters believe they can resist these trends when markets are more "embedded" in local social and environmental contexts (Murdoch, Marsden, \& Banks, 2000). Embeddedness highlights aspects of the local context, such as social relationships, that can modify and sometimes mitigate the workings of a strict, profit-oriented, economic logic, which can disadvantage smaller scale farmers when they enter market relationships. Value chains are one model of short food supply chains that operate regionally and focus on value-added products, including those that are differentiated on the basis of local provenance. By also emphasizing "valuesbased" relationships between supply chain participants and incorporating an ethical element of commitment to fairness, value chains are believed to address the power imbalances that exist in the conventional food system (Stevenson \& Pirog, 2008). In doing so, they ideally improve outcomes for producers, thereby contributing to rural development, while also improving the availability of quality products for consumers.

As local food system development faces the challenges of supplying larger buyers whose needs are not met through direct marketing, more conventional food distribution suppliers have stepped in to source and supply local food (Izumi, Wright, \& Hamm, 2010). We refer to arrangements where conventional food distributors handle local food as "hybrid" food value chains, since they include both local and global resources, and combine conventional food system infrastructure with the alternative goal of building local food systems. How do participants in such hybrid food value chains coordinate their interactions and exchanges? To what extent do hybrid food value chains exhibit the qualities that proponents of alternative food networks attribute to local embeddedness, or do these value chains tend instead to reproduce the power dynamics of the conventional food system?

This paper uses three case studies to explore how hybrid food value chains involving small to midsize produce growers and wholesale produce distributors are coordinated through both informal mechanisms that are related to local embeddedness, such as social relationships, and more formal mechanisms, such as contracts and labels. These case studies, located in rural, urban and exurban regions of Pennsylvania, examine food chains that were not formed with the explicit intent of marketing local produce, and therefore can be considered part of a food system that predates the most recent alternative food movement trends. Because of their hybrid nature, it is important to evaluate whether their embeddedness in a local context 
affects how these value chains are coordinated, including what influence their embeddedness has on producers' capacity to negotiate prices in order to ensure adequate returns. Although local food systems are commonly seen as engines for rural development because they invigorate local market opportunities for producers, our case studies suggest the possibility that some reproduction of conventional food system power dynamics in the local context may undermine this benefit (Marsden, Murdoch, \& Morgan, 1999; Tregear, Arfini, Belletti, \& Marescotti, 2007). While social relationships and personal trust played a role in these case studies, ultimately commercial conventions tended to dominate. At the same time, in hybrid food value chains where producers could secure higher profit margins and negotiating power by marketing a specialized product that was identified as "local," participants faced challenges in finding appropriate mechanisms to coordinate chain relationships. In addition, when marketing a niche product, the question of how to "scale up" local food systems and make local produce more widely available to consumers of all income levels remained unaddressed (Friedmann, 2007).

We begin by describing how hybrid food value chains have been conceptualized, and note a gap in the literature on the role of conventional food system infrastructure in local food system development. Notions of local and social embeddedness help to conceptualize how food chain participants balance their economic and non-economic priorities by coordination through informal and formal mechanisms.

\section{Background and Relevant Literature}

The concept of hybridity arose from a critique of the implied dichotomy between "alternative" and "conventional" food systems. Hybridity recognizes that, in their attempts to reassert control over the food system, producers and consumers may draw from some resources and practices stylized as "conventional" and others as "alternative" (Ilbery \& Maye, 2005; Maye, Kneafsey, \& Holloway, 2007). For example, alternative food networks, such as Fair Trade, tend to utilize conventional food system infrastructure and operating mecha- nisms, while smaller scale producers of specialty foods will "dip in and out" of conventional and alternative resource streams and markets (Ilbery \& Maye, 2005; Whatmore \& Thorne, 1997). These producers' operations are referred to as "hybrid" because they utilize both conventional and alternative resources and markets, and balance economic and non-economic values and goals (Ilbery \& Maye, 2005; Trabalizi, 2007).

In addition to the notion of hybrid enterprises, another type of interaction between the conventional and alternative food systems is the appropriation of alternative food movement terms and claims by market and government actors. For example, many believe that the organic federal standards and the promotion of organic products by mainstream retailers undermine the organic movement's goals and holistic orientation by introducing industrialized practices and values (Guthman, 2004; Jackson, Russell, \& Ward, 2007; Jaffee \& Howard, 2009; Sonnino \& Marsden, 2006). Some researchers and activists clearly see this type of "hybridization" as a threat to alternative food networks, and measure the "alternativeness" of agri-food initiatives by their ability to resist co-optation (Allen, FitzSimmons, Goodman, \& Warner, 2003; Sage, 2003; Sonnino \& Marsden, 2006; Watts, Ilbery, \& Maye, 2005). Hybridity has thus been seen alternately as a necessary, possibly pragmatic feature of some alternative food networks, or as evidence of co-optation.

Very little research or attention has been paid to the actual operation of local food systems that combine conventional infrastructure with local products, and which were not established with the explicit intention of participating in the current local food trend (Bloom \& Hinrichs, 2011; Izumi et al., 2010). These types of hybrid arrangements are influenced by the globalizing trend in the produce industry and therefore source products internationally to ensure year round availability and low prices. At the same time, researchers contend that even while such businesses are intricately tied into global networks, they are never fully disentangled from the influences of their local environment and social context (Gille, 2006; Oosterveer, 2006). For 
example, Murdoch et al. (2000) contend that, "We can question how the local sociomaterial resources of a particular place come to be incorporated into networks or chains dominated by industrial and commercial modes of evaluation," (Murdoch et al., p. 122). This interaction between global processes and local context is highlighted in theories of "local embeddedness," where a wide range of social, cultural, and environmental factors is believed to influence local economic relationships. Local embeddedness draws upon theories of social embeddedness, which describe how economic transactions are mediated by social factors (Granovetter, 1985). These social factors can act as informal mechanisms that coordinate food chain relationships, since personal relationships generate trust and discourage opportunism in economic contexts (Granovetter, 1985; Raub \& Weesie, 1990). Many local food practitioners and advocates support localizing the food system precisely because they believe that social relationships at the local level can take precedence over purely commercial interests, and thereby improve outcomes for local producers (Lyson, 2005).

However, researchers also warn that these local, socialized relationships should not automatically be assumed to be socially just, simply because they are local (DuPuis \& Goodman, 2005). DuPuis and Goodman suggest that it is important to consider the role of local politics and power dynamics: "We have to move away from the idea that food systems become just by virtue of making them local and toward a conversation about how to make local food systems more just" (DuPuis \& Goodman, 2005, p. 364). Hinrichs (2003) suggests a more nuanced approach to studying local food systems that takes into account some of the complexities of local context and states, "While these quite positive aspects of social embeddedness can and do flow from local contexts, local social interactions are not absent of intolerance and unequal power relations" (Hinrichs, 2003, p. 35).

If we resist the assumption that positive benefits automatically result from localizing food chains, it is also important to consider how local and social embeddedness, as potential informal modes of value chain coordination, are balanced with more formalized mechanisms of food chain coordination, specifically contracts and labels. In the conventional food system contracts are usually described in the context of increasingly concentrated and vertically integrated supply chains (Hendrickson \& Heffernan, 2002). Hinrichs and Welsh (2003) and Hendrickson and James (2005) illustrate how the use of contracts in livestock supply chains limits producers' decision-making abilities with regard to his or her operation; this includes decisions that impact environmental sustainability as well as marketing choices. In other situations, however, contracts may be used by downstream actors, such as brokers and processors, as a way to mitigate producers' risks and share information about expectations and standards (Wolf et al., 2001).

In considering formal coordinating mechanisms such as contracts, it is important to note also the role of informal agreements that rely more upon reputation and the promise of repeated transactions rather than any legal enforceability (Raub \& Weesie, 1990; Stevenson \& Pirog, 2008; Wolf et al., 2001). In this way, informal agreements represent a blend of formal and informal mechanisms of coordination, relying in part upon social embeddedness and in part upon interorganizational dynamics. Stevenson and Pirog (2008) discuss this delicate balance between social and commercial pressures in their description of value chains when they consider the implications of informal agreements for typically disadvantaged food chain members. They suggest that despite the role of socially embedded personal trust, more formalized procedural mechanisms may be more important in coordinating successful food value chains, since such procedural mechanisms establish process-based trust. Processbased trust can be thought of as, "Trust in the fairness, stability, and predictability of the procedures and agreements among strategic partners; and that policies are consistent and stable over time, and do not change with new management or personnel" (Stevenson \& Pirog, 2008, p. 125). By suggesting that trust should be interorganizational, Stevenson and Pirog imply that strong food value chains cannot rely solely on personal relationships, 
which are subject to change when key individuals leave organizations. This idea of trust differs from common thinking about many local food initiatives, where personal trust through direct market relations is often seen as both a goal and a central benefit.

Another formal mechanism that helps to coordinate food value chains and regulate quality is the use of labels and brands. Labels communicate quality attributes (such as organic or sustainably produced) and therefore can be important mechanisms, beyond personal interactions, for coordinating and communicating quality. This type of communication is especially important when food supply chains extend beyond direct producerconsumer relationships (Stevenson \& Pirog, 2008). However, the use of labels to differentiate products is only feasible when the labels are recognizable and meaningful to consumers. This has to do with consumer awareness of the quality issues that the label represents, indicating the need for both a strong consumer movement as well as clearly identifiable issues. An engaged and informed consumer base can therefore also be an important element of local embeddedness, since issues related to the local food system must resonate with local buyers before they will make an effort to support local producers or businesses.

In the retail environment of the conventional food system, "Private label products enhance control by retailers who can impose stringent standards on (often captive) suppliers" (Busch, 2007, p. 449). In more localized food value chains, however, labels can be used to shift power and ownership away from retailers and back towards producers. With the growing popularity of local and regionally produced food, producers are increasingly using labels or brands that identify their operation by name (Stevenson \& Pirog, 2008). Stevenson and Pirog (2008) indicate that, "An important mechanism for farmer or rancher empowerment is their retention of control of the food product throughout the value chain, either through actual ownership or maintenance of a farmer- or rancher-based brand through to the consumer," (Stevenson \& Pirog, 2008, p. 130). In this way, labels help to regulate quality and can provide the basis for differentiation of the entire value chain around promotion of the quality of being "local."

Taking these theories and concepts into consideration, we now turn to three case studies of wholesale produce distributors to explore the role of informal and formal mechanisms in coordinating hybrid food value chains.

\section{Research Methods}

This research uses qualitative methods to develop three case studies that explore how hybrid food value chains in Pennsylvania draw on formal and informal mechanisms of coordination. The three cases were originally identified during the course of a research project that examined Farm to School (FTS) programs in the state of Pennsylvania, where school food service directors were asked about their purchasing habits in terms of whatever producers and sources they might consider to be "local" (Hinrichs \& Schafft, 2008). Although FTS programs are often conceptualized as direct marketing initiatives that link producers with school cafeterias, we identified three school districts that purchased local produce through wholesale produce distributors (Healthy Farms and Healthy Schools Act, 2006). These three distributors sourced produce both directly from local producers and globally through conventional channels, and therefore can be considered hybrid enterprises. Their involvement in meeting their local communities' produce needs draws attention to their potential role in building local food systems. These distributors provided points of entry for exploration of three hybrid food value chains. In examining the contexts of the chains that formed around these three distributors, we classify one as rural, one as urban and one as exurban, ${ }^{1}$ based on participants' perceptions and census data.

\footnotetext{
${ }^{1}$ A generally accepted definition of the term "exurban" is hard to find, since many researchers use different parameters to characterize areas that do not fit neatly into urban/rural categorizations. We find the following definition useful: "Exurbs, it is argued, lie somewhere beyond the suburbs. At the urban-rural periphery, outer suburbs bleed into small-town communities with an agricultural heritage. Not yet full-fledged
} 
The boundaries of each case were determined by asking the distributor for the names of those producers and buyers with whom he had an economic relationship and considered to be "local." Using this designation, participants in each case were located within a ten to sixty mile radius from the distributor anchoring that case. In one case, during the course of the initial interview with the distributor, it emerged that an outside organization played an important role facilitating the relationships between the distributor and producers, and therefore the scope of the study was expanded to include this nonprofit actor. For each value chain, this study included three local producers, ${ }^{2}$ one distributor and three local buyers, for a total of 21 study participants overall. Interviews were semistructured and included a series of both fixed and open-ended questions (see a summary of the survey questions in the appendix), thus allowing for comparison across participants while also providing an opportunity for participants to introduce topics that they may have felt were relevant or overlooked by the researcher (Creswell, 2007). In general, interview questions focused on the practices and motivations of participation in the hybrid food value chain that involved the buying and selling of local produce by the wholesale produce distributor. Interview questions aimed to probe the specific case study contexts and to explore themes identified in prior literature. Initial and follow-up interviews were conducted with each distributor; all other study participants were interviewed once. Attempts were made to conduct all interviews in person, although time constraints for one producer necessitated a phone interview. Length of interviews ranged from 20 minutes to two hours, with the average about 45 minutes. All interviews were digitally recorded and transcribed verbatim. Transcriptions were analyzed using a coding approach

suburbs, but no longer wholly rural in nature, these exurban areas are reportedly undergoing rapid change in population, land use and economic function" (Berube, Singer, Wilson, \& Frey, 2006). As a result, exurbs tend to include both blue collar workers and suburbanites seeking a more rural lifestyle (Davis, Nelson \& Dueker, 1994).

${ }^{2}$ Although attempts were made to interview three producers for each case, we were ultimately only able to identify and reach two producers in the urban value chain. that captured relevant theoretical themes, but also allowed unanticipated themes and issues to emerge. In applying qualitative methods, anomalies and inconsistencies are important to consider, since learning from unexpected findings and considering alternate theoretical explanations are important ways that qualitative researchers scrutinize the bases of their analysis and address validity concerns (Creswell, 2007).

In these cases, the three distributors had been involved in the wholesale produce business ranging from 10 to 50 years. These businesses can be considered part of the conventional food system infrastructure in part because they were not established specifically in response to the growing consumer movement around local food and sustainability. In addition, although they purchased some produce directly from local farms and served a purely regional market, they were also very connected to global, conventional supply chains, with the majority of their purchases imported from out of state or internationally and coming through conventional brokers or produce markets. We use the fact that the distributors handled both local and imported produce as selection criteria to classify them as participating in hybrid food value chains. However, the question of how their handling of local produce was incorporated into their conventional operations is a subject of investigation.

In terms of the sample, in 2007 the smallest distributor was in the exurban region and had gross sales between US $\$ 1$ and US $\$ 4$ million, followed by the rural distributor with gross sales between US $\$ 5$ and US $\$ 9$ million, and finally the urban distributor, who grossed between US $\$ 10$ and US\$14 million. The producers in the exurban region had an average size of 16 acres, compared to 225 acres for the rural producers and one or two hydroponic greenhouses for the two producers in the urban region, respectively. The buyers in all three cases included one school district and two restaurants, except in the rural case, which included one farm stand, one restaurant, and one school district. Buyer characteristics that stand out include the large size and tourist attraction designation of the restaurant in the rural case, and the fact that both 
restaurants in the urban case are high end. The influence of local embeddedness on how distributors balance informal and formal mechanisms to coordinate these hybrid food value chains is considered in the next section.

\section{Findings}

Our case study findings highlight how local embeddedness contributes to the way that hybrid food value chains are coordinated and regulated. The analysis reveals distinctions between the rural and exurban cases on the one hand, where participants combined both personal and market-based mechanisms to coordinate their relationships, and the urban case, where the sale of specialty products to a niche market both fostered and inhibited the use of more formal mechanisms of coordination. In the rural and exurban hybrid food value chains, local produce was treated as an undifferentiated commodity, in part due to local consumer perceptions and priorities about food. The relationships between the producers and distributors in these two chains tended to be both personal and dependent on commodity market standards and prices, but without any formalized agreements or labels. In the urban hybrid food value chain, high consumer demand for local produce created a niche for specialty products that allowed this chain to resist some of the common power dynamics in the conventional food system. This value chain, however, still faced challenges in establishing formal coordination mechanisms and in its ability to bring local produce to a more diversified consumer base.

\section{Personal and Market-Based Relationships}

In both the rural and exurban hybrid food value chains, the logic of the conventional food system tended to be reproduced on the local scale. In both these cases, distributors relied on produce industry standards to determine both the price and specifications for local produce. Therefore, trust between producers and the distributors was derived from a combination of personal and market-based mechanisms and not from any interorganizational trust, as suggested by Stevenson and Pirog (2008) in their description of value chains. The personal relationships between producers and distributors in these cases may have fostered a level of trust that helped to maintain their commercial relationships through the development of reputations. However, these personal relationships were ultimately secondary to commercial priorities, and therefore restricted producers' abilities to set prices that reflected their costs, or to negotiate product quality standards with the distributor.

The role of social embeddedness was clear in the rural hybrid food value chain. In this case, the distributor had business relationships with the father of one producer and the grandfather of another; when asked how he began purchasing from this set of local producers, the distributor said, "We all go drinking Friday nights and meet in the bar." $\mathrm{He}$ implied that these social relationships engendered trust, which led these producers to drop off their product before they knew the price that they would receive. While this may indicate a level of social embeddedness for this localized hybrid value chain, this practice was also feasible because prices were nearly exclusively determined by the going prices in nearby produce markets. Therefore, the benefits of personal relationships were not coupled with formalized mechanisms that might enhance processbased and interorganizational trust, as described earlier, but rather remained subject to the potential volatilities of commodity markets. Although there were strong social connections between the producers and the distributor in the rural hybrid food value chain, the producers ran full-time commercial farms that tended to sell only around one percent of their entire sales to the distributor. Therefore their relationship with the distributor was contingent on their having a surplus of products beyond what they sold to their primary broker. This was also related to the fact that the distributor said he was only interested in local products when producers' prices were comparable to the same non-local product, which typically only occurred at the height of the season. As a result, neither the producers nor the distributor was interested in labels that would identify the farm by name, or in any kind of formal agreement to regulate their economic relationship.

The exurban distributor also reflected this combination of informal and formal coordinating mech- 
anisms in determining pricing, and stated that he was honest when sharing information about market prices with producers. He said, "I think they trust me. I'm going to tell them the truth, I'm not going to say, if peppers are fifteen, I'm not going to say, oh they're at ten, I'm going to tell them the truth. And if they want, I'll show them the sheet, you know?" Although he said that producers trusted him, he was also ready to dispel any doubts that they may have had by offering hard evidence in the form of a produce sheet listing current market prices. Again, in this case commercial conventions therefore took precedence over social relationships, despite the role that personal trust might have played. This could also be seen in how the distributor in the exurban hybrid food value chain described his relationship with producers in terms of quality standards. He said:

For example, they'd come in with a zucchini that looked like a baseball bat, and they'd tell me that's what people want. And I'd say, no, that's not what people want. I deliver 12 months a year, they want the smaller one. And if they got belligerent about it, I would just say, don't bother me anymore. That's enough. I get what I want to get, you know, for my customers....I know what they want more than you do! You know how to grow it; I know how to sell it.

Here, the distributor played an important role as the intermediary between producers and the final buyer by coordinating quality between supply and demand. However, from the perspective of the producer, he also did so in a way that exhibited complete control of the relationship between himself and the producer, leaving no room for negotiation. Producers who did not take the information without questioning it, or tried to assert their knowledge of consumer preferences, were denied a business relationship, therefore illustrating the potential instability of these informal marketing relationships.

Another aspect of local embeddedness to consider is consumers' perceptions, which coincide with their willingness to place value on the quality of being "local." Both the rural and exurban distributors were concerned with standardizing their products' prices and quality characteristics in order to diminish the differences between local and nonlocal produce. In the exurban hybrid food value chain, this was partly due to the lack of demand for local products, which the producers and the distributor believed was due to the high proportion of elderly residents and the low socio-economic status of their area's population. In the rural hybrid food value chain, both the distributor and the buyers indicated that consumers identified their region with their agricultural heritage, which in turn led them to feel that the appropriate sources of local produce were farm stands and produce auctions. As a result, buyers in this hybrid value chain primarily used the distributor during the winter months or to supplement regional specialties, such as sweet corn, around the edges of the local season. Since consumer demand for local produce through the distributor was low in both of these cases, more formalized coordinating mechanisms, such as interorganizational agreements or farm-based labels, had little value for the distributors or other participants.

\section{Specialty Products and Niche Demand}

Consumer demand for local products in the urban hybrid food value chain allowed all chain participants to differentiate their businesses around the promotion of local food. Consumers in the urban region appeared to be more connected to a national "buy local" trend than in either the rural or exurban regions. In this chain, specialty products, such as hydroponic lettuce and micro-greens, were destined for a niche market of high-end restaurants. As a result, selling differentiated products allowed producers the freedom and power to set their prices based on their costs. In this food value chain, while there was the potential for contracts to coordinate supply and demand, the implementation of such formal mechanisms faced challenges. In addition, labels served an important function, although a lack of interorganizational trust may have impeded their usefulness. Finally, because of the nature of the specialty products studied in this hybrid value chain, using conven- 
tional infrastructure may not have contributed to scaling up the local food system in this region in order to reach a wider consumer base.

To begin, hybrid food value chain participants in the urban area recognized the value that being "local" gave their products. The producers, distributor and restaurants all differentiated their businesses based on the fact that they grew, sold, and served local products. Because of this interest in local produce, the power dynamics in this value chain appear to have been shifted slightly in favor of the producers, who set their own prices and were able to negotiate with the distributor irrespective of the going prices in the conventional produce markets for the products that they sold. For example, one producer described how he received steady prices throughout the season and calculated these prices based on his costs:

In the last year we've held all of our prices steady — they haven't changed. Now, what I'll do at the end of the summer is go to [the Distributor] and I'll try to get an increase, because my costs have increased, especially because, minimum wage is going up again, and once minimum wage goes up, it just bumps everything else up. So once a year I like to go to those guys and say, I need an increase.

This producer found that he could earn more selling wholesale to the distributor, where he charged by the pound, than he could selling directly to consumers, where he charged per head of lettuce. In this case, such a dynamic challenges the common belief that direct marketing provides higher profit margins, which is interesting to note since this small scale farmer was not benefitting from economies of scale, but rather from participating in a value chain that rewarded him for the quality of being local. The other producer in the urban hybrid food value chain said that his product "isn't really a commodity" because it could be marketed as a local item. By incorporating this non-economic value into his judgment of quality, the producer was able to subvert the more commercial logic of the conventional produce industry. He combined the value of "being local" with a commercial imperative to make a profit in order to stay in business. However, the distributor also made it clear that while he was willing to accept producers' prices for specialty products, he relied on commodity pricing for more generic products, or when he sold to buyers with price constraints, such as the school district.

Despite the incorporation of non-economic values into quality definitions for the urban hybrid food value chain, this chain experienced challenges in coordination and regulation in the area of contracts and labels. Although the distributor maintained consistent relationships with the two producers interviewed for the purposes of this case study, when he reflected on his ability to expand his local sourcing he exhibited obvious frustration. This was because the popularity of local produce in the urban region facilitated producers' ability to sell their products through multiple profitable channels, leaving the distributor to struggle to maintain consistent relationships with producers. As a result, he believed that developing contracts would be the best way to receive steady produce at reasonable prices. He reflected on his need for contracts with local producers, and his hope that an actor from the statewide nonprofit would be able to facilitate them, as follows:
So that's why I hope that [Nonprofit
Actor] will be able to contract and say all right, if you want [Distributor] to guarantee you 60 cases of peppers a week, you've got to be within $\mathrm{X}$ amount of dollars of the Produce Yards, whatever the market is bearing at that point. So that was the issue I ran into over the summer, I called some of these farmers up and said this is what I need, and here's the price, and I'm selling it to my customers cheaper than what you want to sell it to me!

The distributor in the urban context described himself as "irritated" by the fact that local producers desired the flexibility to choose their markets depending on where they could get a better price at any given moment, as well as by the high prices 
that they demanded. The distributor was unable to develop contracts with local growers, and the nonprofit actor was uninterested in mediating this aspect of the coordination of the hybrid food value chain. She said, "That's between him and the farmer. That's not something that I've worked on; any contract that [the Distributor] has with a farmer is strictly his business. I do not think [the nonprofit] should be involved with that." Here the nonprofit actor drew a line of how involved she believed that she and her organization should be; she suggested that facilitating the relationships between the distributor and producers should be limited to initiating, and not maintaining, these relationships.

Another coordinating mechanism that created a challenge for the urban hybrid food value chain was farm-based labels. Both of the producers in this particular hybrid food value chain used labels, which allowed them to communicate the non-economic value of their spatial proximity to consumers. As described earlier, Stevenson and Pirog (2008) suggest that farm-based labels can help shift power towards producers by allowing them more control over the product and a price premium. However, in the urban hybrid food value chain, producers suggested that their farm-based labels did not provide them the level of control they desired. While these labels helped them secure a price premium, the producers also saw risks if the product was not handled properly by the distributor, since the end consumer's judgment, through the label, reflected on the producers' operations. Therefore, despite the use of a formal coordination mechanism, a lack of interorganizational trust inhibited producers from experiencing the full benefits that using labels might provide. Although the producers in the urban hybrid food value chain benefited economically from being able to promote specialized product attributes, chain participants still struggled to find appropriate mechanisms for coordinating and regulating quality.

Finally, the specialty producers' small scale and the limited nature of the outlets for their products (which included high-end restaurants but excluded larger buyers, such as the school district), may mean that this type of local hybrid food value chain would have a limited contribution toward scaling up the local food system (Friedmann, 2007). This, in turn, would keep it from influencing the local economy in terms of rural development or making local produce more accessible to more types of consumers to address food security concerns.

\section{Conclusion}

In this study, the small sample size and focus on one particular state (Pennsylvania) restricts our ability to generalize the results to other instances of hybrid food value chains. However, the examination of informal and formal coordinating mechanisms linked to aspects of local embeddedness reveals suggestive patterns and themes that could offer insights and guidance for considering how hybrid food value chains might operate in other places. This study found that local food systems that combine conventional infrastructure with local production and consumption tended to prioritize market-based considerations despite their local embeddedness. This finding challenges some of the assumptions about the role of embeddedness in local food systems, namely that the social and cultural context will strongly modify or mitigate some of the economic logic in market relationships that tends to disadvantage small to mid-size producers. This study found that the participants in the urban hybrid food value chain were better able to resist a purely market-based logic, as producers had greater negotiating and price-setting power. However, as a result, this value chain ran the risk of being restricted to niche production, which then inhibited its contribution to improving food security. In contrast, in the rural and exurban cases, local food was treated more as a commodity with little to no differentiation, and as a result the distributors had little motivation to actively source or promote local produce. In these two cases, the type of mid-size family farms that researchers suggest should be particularly well positioned to participate in value chains seemed locked into the mentality and operating mechanisms of the mainstream food system. This was true even where social considerations mediated economic relationships, suggesting that social and local embeddedness may not be sufficient factors to foster successful hybrid food value chains. 
These findings raise questions about how the design and organization of value chains should incorporate and balance informal and formal mechanisms of coordination in order to generate benefits for producers, consumers and intermediaries. In the urban hybrid food value chain, the use of a formal mechanism, labels, did not achieve the desired benefit of a redistribution of power, perhaps because such labels were not coupled with some of the more informal aspects of interorganizational trust. In this case, contextual market factors also impeded the development of contracts as another potential formal coordinating mechanism. On the other hand, in the rural and exurban hybrid food value chains, informal mechanisms, in the form of personal relationships, did not contribute to securing arrangements that were economically viable. In none of the cases did we find the type of interorganizational agreements that would generate process-based trust, which has been suggested to be critical for successful value chain development (Stevenson \& Pirog, 2008). As a way of combining both formal and informal mechanisms, interorganizational agreements could be a useful focus for developing hybrid food value chains.

As policy and practitioner interest shifts to examine new models for the aggregation and distribution of produce, the role of conventional distributors in regional food system development has arisen in other contexts, particularly in terms of food hubs. A food hub is loosely defined as, "a centrally located facility with a business management structure facilitating the aggregation, storage, processing, distribution, and/or marketing of locally/ regionally produced food products" (Barham, 2010). In much the same way that we identified distributors who inadvertently coordinated value chains, other researchers suggest that many traditional wholesalers have become "de facto" food hubs (Morley, Morgan, \& Morgan, 2008). In both the value chain and food hub example, since wholesale produce distributors already perform the functions of aggregation and distribution, harnessing their expertise and facilities provides a natural extension for local food system development (Barham, 2010). Indeed, these local food system models may benefit from the involvement of individuals with this type of commercial experience and business savvy (Morley et al., 2008).

At the same time, however, both our findings and other research suggest that the commercial motivations of conventional distributors may not be compatible with other sustainability goals of local food systems (Morley et al., 2008). Many of the tensions we identified in this study were specific to actors who are accustomed to working within the conventional expectations of the produce industry. This was true for both producers and distributors, who may be able to perceive how traditionally structured supply chains disadvantage them, but who nonetheless find it challenging to embrace new business models and work outside the logic of the conventional food system. In the cases studied here, even formal mechanisms of value chain coordination were often unsuccessful, in part because hybrid food value chain participants had expectations for others' actions that were based on the power dynamics of the conventional system. Subverting these power dynamics does not automatically arise from the quality of being local, and therefore implementing hybrid food value chains requires a concerted and committed effort on the part of participants. Part of this effort must be the explicit incorporation of non-economic goals. For example, while food hubs in essence serve as value chains that move produce between growers and consumers, many of these organizations form as nonprofits, or attempt to create a space that fosters other types of interaction, such as community kitchens or farmer education and training sessions (Barham, 2010). Similarly, the Agriculture of the Middle working group has identified several value chains that "piggyback" on conventional food system infrastructure, yet maintain a commitment to the ethical component of the value chain framework (Stevenson \& Pirog, 2008). Hybrid food value chains, or other models of produce aggregation and distribution that rely on conventional infrastructure to build local food systems, therefore may benefit from this type of more deliberate engagement with the values-based element of value chains (Bloom \& Hinrichs, 2011; Stevenson \& Pirog, 2008). 
Further research could be done to see whether openly committing to these non-economic goals helps new models of produce aggregation and distribution to have more success when they integrate conventionally-oriented businesses and enterprises into their networks. As the examples above suggest, the incorporation of individuals and businesses from the conventional food sector into hybrid value chains may not necessarily or automatically lead to the re-creation of a conventional food system mentality. Attention to the importance of communication and negotiation between all participants in hybrid food value chains may help articulate common goals and identify the mix of coordinating mechanisms that can best serve those goals.

\section{Acknowledgements}

This research was supported in part by a grant from the Center for Rural Pennsylvania, a legislative agency of the Pennsylvania General Assembly. Information provided does not necessarily reflect the views of individual board members or the Center for Rural Pennsylvania.

\section{References}

Allen, P., FitzSimmons, M., Goodman, M., \& Warner, K. (2003). Shifting plates in the agrifood landscape: The tectonics of alternative agrifood initiatives in California. Journal of Rural Studies, 19(1), 61-75. http://dx.doi.org/10.1016/S0743-0167(02)00047-5

Barham, E. (2002). Towards a theory of values-based labeling. Agriculture and Human V alues, 19, 349-360. http://dx.doi.org/10.1023/A:1021152403919

Barham, J. (2010, December 14). Getting to Scale with Regional Food Hubs. Know Your Farmer, Know Your Food. USDA Agricultural Marketing Service. Retrieved from http://kyf.blogs.usda.gov/ category/regional-food-hub/

Berube, A., Singer, A., Wilson, J., \& Frey, W. (2006). Finding exurbia: America's fast-growing communities at the metropolitan fringe. The Brookings Institute Living Cities Census Series. Retrieved from http://www.brookings.edu/reports/2006/ 10 metropolitanpolicy berube.aspx

Bloom, J. D., \& Hinrichs, C. C. (2011). Moving local food through conventional food system infrastructure: Value chain framework comparisons and insights. Renewable Agriculture and Food Systems, 26, 13-23. http://dx.doi.org/10.1017/
$\underline{\mathrm{S} 1742170510000384}$

Busch, L. (2007). Performing the economy, performing science: from neoclassical to supply chain models in the agrifood sector. Economy and Society, 36(3), 437-466. http://dx.doi.org/10.1080/ $\underline{03085140701428399}$

Creswell, J. W. (2007). Qualitative inquiry and research design: Choosing among five approaches (2nd ed.). Thousand Oaks, CA: Sage.

Davis, J. S., Nelson, A. C., \& Dueker, K. J. (1994). The new 'burbs. The exurbs and their implications for planning policy. Journal of the American Planning Association, 60(1), 45. http://dx.doi.org/10.1080/ 01944369408975551

DuPuis, E. M., \& Goodman, D. (2005). Should we go "home" to eat?: Toward a reflexive politics of localism. Journal of Rural Studies, 21(3), 359-371. http://dx.doi.org/10.1016/j.jrurstud.2005.05.011

Friedmann, H. (2007). Scaling up: Bringing public institutions and food service corporations into the project for a local, sustainable food system in Ontario. Agriculture and Human V alues, 24, 389-398. http://dx.doi.org/10.1007/s10460-006-9040-2

Gille, Z. (2006). Detached flows or grounded placemaking projects? In G. Spaargaren, A. P. J. Mol, \& F. Buttel (Eds.), Governing Environmental Flows: Global Challenges to Social Theory (pp. 137-156). Cheltenham, UK: The MIT Press.

Granovetter, M. S. (1985). Economic action and social structure: The problem of embeddedness. The American Journal of Sociology, 91(3), 481-510. http://dx.doi.org/10.1086/228311

Guthman, J. (2004). Agrarian dreams: The paradox of organic farming in California. Berkeley, CA: University of California Press.

Healthy Farms and Healthy Schools Act. (2006). Retrieved from http://www.legis.state.pa.us/ CFDOCS/Legis/PN/Public/btCheck.cfm?txtType =HTM\&sessYr=2005\&sessInd $=0 \& b i l l B o d y=$ $\underline{\text { S\&billTyp }=\text { B\&billNbr }=1209 \& p n=2047}$

Hendrickson, M. K., \& Heffernan, W. D. (2002). Opening spaces through relocalization: Locating potential resistance in the weaknesses of the global food system. Sociologia Ruralis, 42(4), 347-369. http://dx.doi.org/10.1111/1467-9523.00221

Hinrichs, C. C. (2000). Embeddedness and local food systems: Notes on two types of direct agricultural market. Journal of Rural Studies, 16(3), 295-303. http://dx.doi.org/10.1016/S0743-0167(99)00063-7

Hinrichs, C. C. (2003). The practice and politics of food system localization. Journal of Rural Studies, 19(1), 33-45. http://dx.doi.org/10.1016/S07430167(02)00040-2 
Hinrichs, C. C., \& Schafft, K. (2008). Farm to school programs in Pennsylvania. Center for Rural Pennsylvania. Retrieved from http://www.ruralpa. org/farm_school_report08.pdf

Hinrichs, C. C., \& Welsh, R. (2003). The effects of the industrialization of US livestock agriculture on promoting sustainable production practices. Agriculture and Human Values, 20, 125-141. http://dx.doi.org/10.1023/A:1024061425531

Ilbery, B., \& Maye, D. (2005). Food supply chains and sustainability: Evidence from specialist food producers in the Scottish/English borders. Land Use Policy, 22(4), 331-344. http://dx.doi.org/ 10.1016/j.landusepol.2004.06.002

Izumi, B., Wright, D., \& Hamm, M. (2010). Farm to school programs: Exploring the role of regionallybased food distributors in alternative agrifood networks. Agriculture and Human Values, 27(3), 335350. http://dx.doi.org/10.1007/s10460-009-9221-x

Jackson, P., Russell, P., \& Ward, N. (2007). The appropriation of "alternative" discourses by "mainstream” food retailers. In D. Maye, L. Holloway, \& M. Kneafsey (Eds.), Alternative Food Geographies (pp. 309-330). Oxford, UK: Elsevier Ltd.

Jaffee, D., \& Howard, P. H. (2009). Corporate cooptation of organic and fair trade standards. Agriculture and Human Values (Online).

Kirwan, J. (2006). The interpersonal world of direct marketing: Examining conventions of quality at UK farmers' markets. Journal of Rural Studies, 22(3), 301-312. http://dx.doi.org/10.1016/j.jrurstud. 2005.09.001

Lyson, T. A. (2005). Civic agriculture and community problem solving. Culture \& Agriculture, 27(2), 92-98. http://dx.doi.org/10.1525/cag.2005.27.2.92

Marsden, T., Murdoch, J., \& Morgan, K. (1999). Sustainable agriculture, food supply chains and regional development: Editorial introduction. International Planning Studies, 4(3), 295-301. http://dx.doi.org/10.1080/13563479908721743

Maye, D., Kneafsey, M., \& Holloway, L. (2007). Introducing alternative food geographies. In D. Maye, L. Holloway, \& M. Kneafsey (Eds.), Alternative Food Geographies (pp. 1-20). Oxford: Elsevier Ltd.

Morley, A., Morgan, S., \& Morgan, K. (2008). Food Hubs: The "Missing Middle" of the Local Food Infrastructure? Cardiff University: BRASS Centre. Retrieved from http://www.brass.cf.ac.uk/ uploads/Food HubKM0908.pdf
Murdoch, J., Marsden, T., \& Banks, J. (2000). Quality, nature, and embeddedness: Some theoretical considerations in the context of the food sector. Economic Geography, 76(2), 107-125. http://dx.doi.org/10.2307/144549

Oosterveer, P. (2006). Environmental governance of global food flows: The case of labeling strategies. In G. Spaargaren, A. P. J. Mol, \& F. Buttel (Eds.), Governing environmental flows: Global challenges to social theory (pp. 268-301). Cambridge, MA: MIT Press.

Raub, W., \& Weesie, J. (1990). Reputation and efficiency in social interactions: An example of network effects. The American Journal of Sociology, 96(3), 626-654. http://dx.doi.org/10.1086/229574

Sage, C. (2003). Social embeddedness and relations of regard: Alternative "good food" networks in south-west Ireland. Journal of Rural Studies, 19(1), 47-60. http://dx.doi.org/10.1016/S07430167(02)00044-X

Sonnino, R., \& Marsden, T. (2006). Beyond the divide: Rethinking relationships between alternative and conventional food networks in Europe. Journal of Economic Geography, 6(2), 181-199. http://dx.doi. org/10.1093/jeg/lbi006

Stevenson, G., \& Pirog, R. (2008). Values-based supply chains: Strategies for agrifood enterprises of the middle. In T. A. Lyson, G. Stevenson, \& R. Welsh (Eds.), Food and the mid-level farm (pp. 119-143). Cambridge, MA: The MIT Press.

Trabalizi, F. (2007). Crossing conventions in localized food networks: Insights from southern Italy. Environment and Planning A, 39, 283-300. http://dx.doi.org/10.1068/a37247

Tregear, A., Arfini, F., Belletti, G., \& Marescotti, A. (2007). Regional foods and rural development: The role of product qualification. Journal of Rural Studies, 23(1), 12-22. http://dx.doi.org/10.1016/ j.jrurstud.2006.09.010

Watts, D. C. H., Ilbery, B., \& Maye, D. (2005). Making reconnections in agro-food geography: Alternative systems of food provision. Progress in Human Geography, 29(1), 22-40. http://dx.doi.org/10.1191/ 0309132505ph526oa

Whatmore, S., \& Thorne, L. (1997). Nourishing networks: Alternative geographies of food. In D. Goodman, \& M. Watts (Eds.), Globalising food: Agrarian questions and global restructuring (pp. 287304). London: Routledge.

Wolf, S., Hueth, B., \& Ligon, E. (2001). Policing mechanisms in agricultural contracts. Rural Sociology, 66(3), 359-381. http://dx.doi.org/10.1111/j.15490831.2001.tb00072.x 


\section{Appendix. Summary of Questions Asked During Interview Process}

This table summarizes the survey questions asked for each type of respondent; the complete questions are not shown. The interviews were semistructured and therefore the questions were used as a general guide, but participants had the freedom to elaborate on issues they perceived to be the most relevant.

\begin{tabular}{|c|c|c|c|}
\hline Question Type & Producers & Distributors & Buyers \\
\hline \multicolumn{4}{|l|}{ General Information } \\
\hline Number of years in current line of work & $\mathrm{x}$ & $\mathrm{x}$ & $\mathrm{x}$ \\
\hline How entered this line of work & & $\mathrm{x}$ & $\mathrm{x}$ \\
\hline Description of business & $\mathrm{x}$ & & $\mathrm{x}$ \\
\hline Number of employees & $\mathrm{x}$ & $\mathrm{x}$ & $\mathrm{x}$ \\
\hline Gross sales or scale of business & $\mathrm{x}$ & $\mathrm{x}$ & $\mathrm{x}$ \\
\hline Percentage of gross sales by market type & $\mathrm{x}$ & $\mathrm{x}$ & \\
\hline Where purchase inputs or produce & $\mathrm{x}$ & $\mathrm{x}$ & $\mathrm{x}$ \\
\hline Definition of local & $\mathrm{x}$ & $\mathrm{x}$ & $\mathrm{x}$ \\
\hline How buying local fits into overall buying practices & & $\mathrm{x}$ & $\mathrm{x}$ \\
\hline \multicolumn{4}{|l|}{ Experience Marketing } \\
\hline How initiated relationship with other value chain participant & $\mathrm{x}$ & $\mathrm{x}$ & $\mathrm{x}$ \\
\hline Description of relationship with other value chain participant & $\mathrm{x}$ & $\mathrm{x}$ & $\mathrm{x}$ \\
\hline How determined price of products and perception of fairness & $\mathrm{x}$ & $\mathrm{x}$ & \\
\hline How changed operations to fit demands from buyers & $\mathrm{x}$ & $\mathrm{x}$ & \\
\hline How promoted local purchases & & & $\mathrm{x}$ \\
\hline Nature of customer demand & & & $\mathrm{x}$ \\
\hline How business affected by local produce offerings & & & $\mathrm{x}$ \\
\hline Expectations for continued local produce purchasing & & & $\mathrm{x}$ \\
\hline \multicolumn{4}{|l|}{ Experiences Purchasing } \\
\hline Decision and experience buying local produce & & $\mathrm{x}$ & $\mathrm{x}$ \\
\hline Type of information exchanged between seller and buyer & $\mathrm{x}$ & $\mathrm{x}$ & \\
\hline Nature of purchasing agreements & $\mathrm{x}$ & $\mathrm{x}$ & \\
\hline Willingness to pay more for local products & & & $\mathrm{x}$ \\
\hline Comparison of local produce sources & & & $\mathrm{x}$ \\
\hline Benefits of purchasing or selling local produce & $\mathrm{x}$ & $\mathrm{x}$ & $\mathrm{x}$ \\
\hline Challenges of purchasing or selling local produce & $\mathrm{x}$ & $\mathrm{x}$ & $\mathrm{x}$ \\
\hline Use of labels or certifications & $\mathrm{x}$ & $\mathrm{x}$ & $\mathrm{x}$ \\
\hline Benefits and drawbacks of certification and/or label programs & & $\mathrm{x}$ & \\
\hline Perception of potential results of building a more localized food system & $\mathrm{x}$ & $\mathrm{x}$ & $\mathrm{x}$ \\
\hline \multicolumn{4}{|l|}{ Personal Information } \\
\hline How many years of formal education, and what specialty & $\mathrm{x}$ & $\mathrm{x}$ & $\mathrm{x}$ \\
\hline Description of setting where individual grew up & $\mathrm{x}$ & $\mathrm{x}$ & $\mathrm{x}$ \\
\hline Additional employment beyond this operation & $\mathrm{x}$ & & \\
\hline Current plans for continuing this operation or passing it on & $\mathrm{x}$ & & \\
\hline
\end{tabular}

